\title{
Recent advances in branching mechanisms underlying
}

\section{neuronal morphogenesis [version 1; peer review: 2 approved]}

\author{
Shalini Menon'1, Stephanie Gupton (101-3 \\ ${ }^{1}$ Department of Cell Biology and Physiology, The University of North Carolina at Chapel Hill, Chapel Hill, Chapel Hill, NC, 27599, USA \\ ${ }^{2}$ Neuroscience Center, The University of North Carolina at Chapel Hill, Chapel Hill, NC, 27599, USA \\ ${ }^{3}$ Lineberger Comprehensive Cancer Center, University of North Carolina at Chapel Hill, Chapel Hill, NC, 27599, USA
}

V1 First published: 12 Nov 2018, 7(F1000 Faculty Rev):1779

https://doi.org/10.12688/f1000research.16038.1

Latest published: 12 Nov 2018, 7(F1000 Faculty Rev):1779

https://doi.org/10.12688/f1000research.16038.1

\section{Abstract}

Proper neuronal wiring is central to all bodily functions, sensory perception, cognition, memory, and learning. Establishment of a functional neuronal circuit is a highly regulated and dynamic process involving axonal and dendritic branching and navigation toward appropriate targets and connection partners. This intricate circuitry includes axo-dendritic synapse formation, synaptic connections formed with effector cells, and extensive dendritic arborization that function to receive and transmit mechanical and chemical sensory inputs. Such complexity is primarily achieved by extensive axonal and dendritic branch formation and pruning. Fundamental to neuronal branching are cytoskeletal dynamics and plasma membrane expansion, both of which are regulated via numerous extracellular and intracellular signaling mechanisms and molecules. This review focuses on recent advances in understanding the biology of neuronal branching.

\section{Keywords}

actin, microtubules, exocytosis, branching, arborization, gene expression, activity

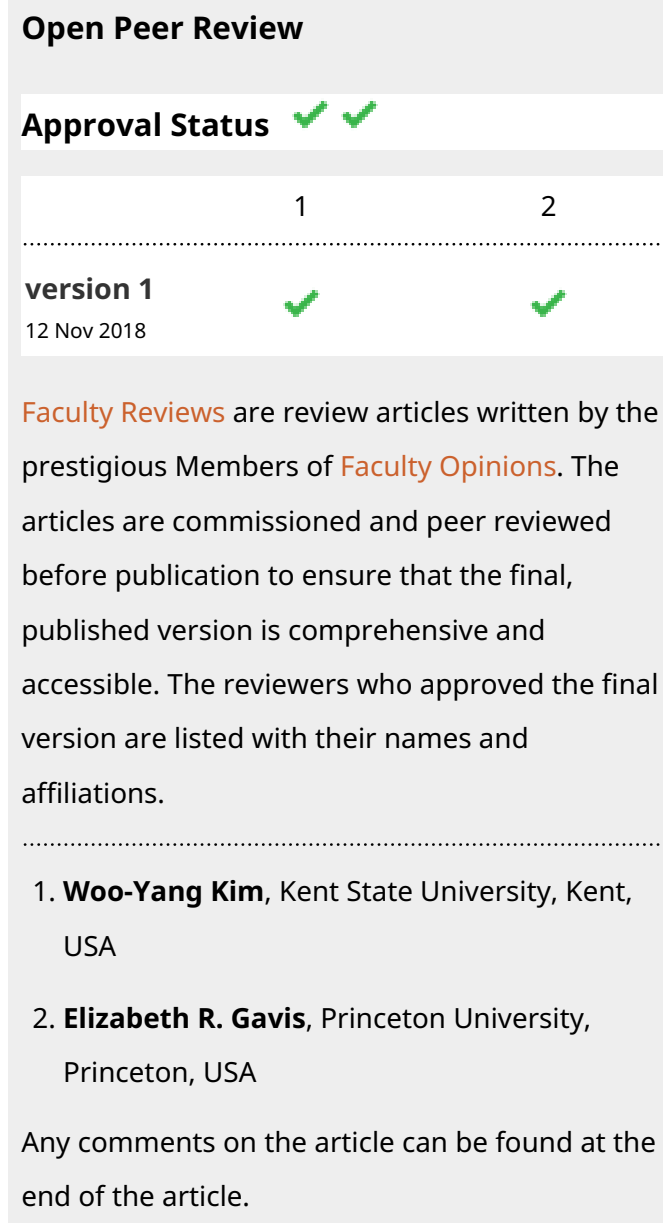

1. Woo-Yang Kim, Kent State University, Kent, USA

2. Elizabeth R. Gavis, Princeton University,

Princeton, USA

Any comments on the article can be found at the end of the article. 
Corresponding author: Stephanie Gupton (sgupton@email.unc.edu)

Author roles: Menon S: Conceptualization, Data Curation, Writing - Original Draft Preparation; Gupton S: Conceptualization, Funding Acquisition, Project Administration, Writing - Review \& Editing

Competing interests: No competing interests were disclosed.

Grant information: This work was supported in part by the National Institute of General Medical Sciences (GM108970). The funders had no role in study design, data collection and analysis, decision to publish, or preparation of the manuscript.

Copyright: ๑ 2018 Menon S and Gupton S. This is an open access article distributed under the terms of the Creative Commons Attribution License, which permits unrestricted use, distribution, and reproduction in any medium, provided the original work is properly cited.

How to cite this article: Menon $\mathrm{S}$ and Gupton $\mathrm{S}$. Recent advances in branching mechanisms underlying neuronal morphogenesis [version 1; peer review: 2 approved] F1000Research 2018, 7(F1000 Faculty Rev):1779 https://doi.org/10.12688/f1000research.16038.1

First published: 12 Nov 2018, 7(F1000 Faculty Rev):1779 https://doi.org/10.12688/f1000research.16038.1 


\section{Introduction}

Elaborate branched structures are present across fungi, plant, and animal kingdoms. These beautiful forms are paramount to function, including mycelial colonization, plant vascularization, and the physiological functions of the circulatory, respiratory, renal, and nervous systems. The unifying consequence of branching is maximization of surface area, used for self-propagation, efficient exchange of gases and fluids, or storing and relaying of information. Experimental science, mathematical studies, and computational modeling have revealed numerous mechanisms and underlying principles of branching morphogenesis in organisms, organs, and single cells such as neurons. General reviews on branching morphogenesis have been recently published ${ }^{1-4}$. Here we focus on recent advances in neuronal branching morphogenesis.

Mature neuronal circuitry comprises an astounding density of synapses between axons and dendrites or between neurons and effector cells. The capacity of a single axon to form multiple synapses is facilitated by axonal branching, which occurs via bifurcation of the tip of the extending axon or collateral branching from the axon shaft. Dendrite arborization increases synaptic capacity but is also essential for sensory perception. Dendritic arborization patterns are strikingly different between neuronal types and are dictated by the number and types of synaptic or sensory inputs received and the geometry and size of the receptive fields. The extensively branched phenotypes of neurons were elaborately depicted by Santiago Ramón y Cajal in the 19th century and have since been an area of extensive research. Failure to establish proper branching patterns and circuitry leads to various neurodevelopmental and neuropsychiatric disorders $^{5-10}$.

Branching morphogenesis is a "Herculean task", which at its foundation involves dramatic plasma membrane expansion and dynamic cytoskeletal reorganization ${ }^{11-15}$ (Figure 1). Plasma

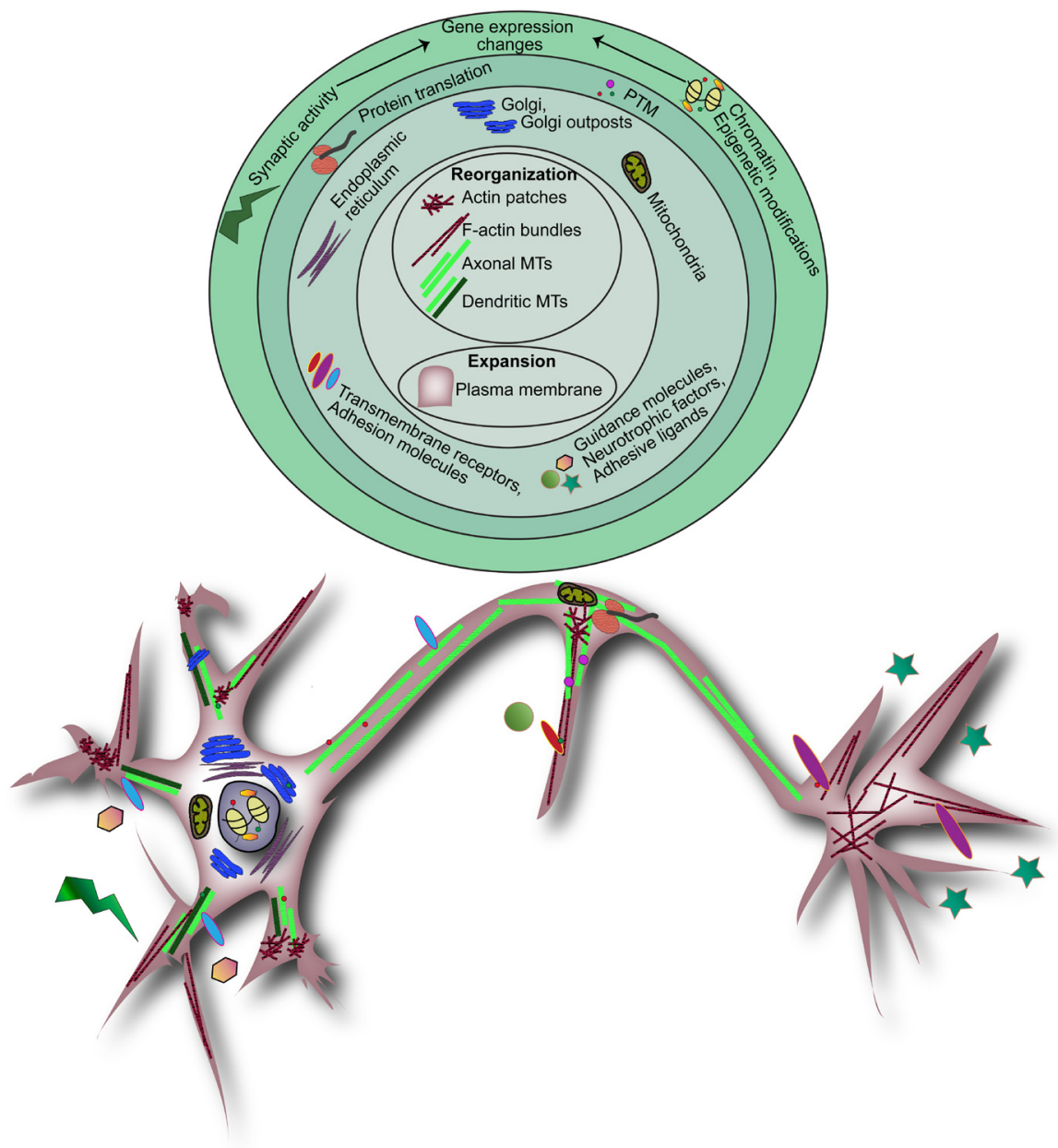

Figure 1. Hierarchical events of neuronal branching. Neuronal branching is a coordinated process that requires extensive filamentous actin and microtubule (MT) reorganization and plasma membrane expansion, depicted in the center of the branching hierarchy. These foundational events are spatially and temporally regulated by numerous signaling and mechanical pathways in a coordinated fashion. These pathways are initiated in response to synaptic activity, extracellular guidance molecules, neurotrophic factors, or adhesive ligands. This outside-in signaling results in extensive cytoskeletal and membrane changes regulated directly through signal transduction, transport and sorting of organelles and cargo-carrying vesicles, and energy production or indirectly through gene expression changes via transcriptional regulation, epigenetic modifications, post-transcriptional and post-translational modifications (PTMs), and local protein synthesis. 
membrane expansion in developing neurons is facilitated by the insertion of new membrane material via exocytosis ${ }^{11,16}$. A classic hypothesis suggests that membrane is added at sites of cell growth, such as the tips of neurites ${ }^{17,18}$. An alternative hypothesis suggests that membrane is added distally and membrane material flows laterally toward neurite tips ${ }^{16}$. Visualization of exocytic hotspots clustered in the soma of neurons indicates that new membrane material is primarily added to the soma ${ }^{16}$. Although this suggests that lateral membrane diffusion or flow carries membrane material to neurite tips, the dynamics of membrane flow and whether it differs in dendrites and axons are yet to be defined.

In the developing neuron, the cytoskeleton is mainly composed of actin filaments and microtubules (MTs), which each undergo extensive polymerization, depolymerization, and reorganization in response to intrinsic and extrinsic cues. Interactions between actin and MTs mediated by actin and MT crosslinking proteins, such as the spectroplakin family member MACF1 ${ }^{19,20}$, help orchestrate cytoskeletal rearrangement and stability ${ }^{21}$. Nascent branches along the axon and dendrites emerge as actin-rich protrusions known as filopodia. MT invasion of filopodia precedes branch extension and maturation. Classic literature demonstrated that cytoskeletal dynamics and organization differ between axons and dendrites during growth and branching. In the axon, actin forms evenly spaced ring-like structures along the axon shaft ${ }^{22}$. Actin hotspots observed along axons produce long filamentous actin structures referred to as actin trails ${ }^{23,24}$. In contrast, cortical F-actin is described in dendrites and dendritic spines ${ }^{14}$. MTs in the axon are oriented with their plus-ends outward ${ }^{25-29}$. In contrast, dendritic MTs exhibit mixed polarity with $50-90 \%$ of their minus-ends oriented away from the soma, dependent upon the organism and neuron type $\mathrm{e}^{25,26,30-32}$. The different organization of the cytoskeleton likely underlies differences in cellular architecture and indicates that different regulatory mechanisms for cytoskeletal rearrangement occur in the axon and dendrite.

Local changes in cytoskeletal architecture and plasma membrane addition needed for branching are modulated by activitydependent and activity-independent mechanisms in a temporally and spatially regulated manner. Extracellular factors such as guidance molecules, neurotrophic factors, and adhesive ligands and their receptors together with intrinsic factors such as organelle position and gene expression initiate and regulate signaling pathways that ultimately converge on the cytoskeleton or exocytic and endocytic machinery to fuel branching (Figure 1). Here we concentrate on recent advances made in the last three years as an update to classic and recent reviews that illustrate the extensive work that has identified the extracellular and intrinsic factors that regulate neuronal branching ${ }^{12,13,33-49}$. Although cross-talk between pathways and mechanisms complicates distinction between various factors that regulate branching, we organize recent advances under several broad categories.

\section{Cytoskeletal changes influence branching}

Actin dynamics are critical to axonal and dendritic branching ${ }^{12-14,33,37,42,45}$. Monomeric actin polymerizes to form filamentous actin, which organizes into higher-order structures such as bundles, branched networks, patches, rings, waves, and trails. Multiple isoforms of actin fuel neuronal branching. $\beta$-actin is locally translated in distal axons, where it supports axonal growth ${ }^{50,51}$. The $\alpha$-actin isoform is also locally translated and enriched at axonal branch points, where it is critical for collateral branching in motoneurons ${ }^{52}$. Filopodial protrusions emerge from actin patches preceding branch formation ${ }^{53}$. In Caenorhabditis elegans, the Wnt family of secreted glycoproteins initiates a signaling cascade via endocytosis of its receptor Frizzled that results in actin patch formation and branch initiation sites along the PLM mechanosensory neurons ${ }^{54}$. Similarly, "actin blobs" mark branch initiation sites along dendrites in Drosophila class IV dendritic arborization neurons ${ }^{55}$. At such branch initiation sites, actin-binding proteins facilitate the reorganization of actin architecture. In C. elegans, the actin branching Arp2/3 complex is regulated during dendritic arborization by dendritic membrane proteins DMA1 and the claudin protein HPO-30, which form a scaffolding complex for the RacGEF TIAM-1 and WAVE regulatory complex ${ }^{56}$. Spectrinactin binding and dynamics are also important for dendritic branching and elongation. An actin-binding domain mutation of $\beta$-III-spectrin seen in spinocerebellar ataxia results in tight binding of $\beta$-III-spectrin to actin and their accumulation in the soma, leading to reduced dendritic branching in Drosophila dendritic arborization sensory neurons $\mathrm{s}^{57}$.

MTs help establish and maintain neuronal networks by stabilizing and extending axons, dendrites, and their branches and serving as tracks for motor-based transport $\mathrm{t}^{12,15,33,37,42,45,58}$. MTs are composed of 13 laterally associated protofilaments of $\alpha$-tubulin and $\beta$-tubulin heterodimers polymerized in a head-to-tail fashion. Tubulin folding cofactor D (TBCD) facilitates $\alpha \beta$-tubulin heterodimerization ${ }^{59}$; non-optimal levels of TBCD result in MT disruption and ectopic dendritic arborization ${ }^{60}$. Filopodia and nascent branches are stabilized by MT entry and destabilized by MT retreat. Growth and catastrophe of MTs are promoted by MT-associated proteins (MAPs) and tubulin post-translational modifications (PTMs) including acetylation, phosphorylation, and polyglutamylation. MAP7 colocalizes with stable acetylated MTs at axon branch points and promotes collateral branching ${ }^{61}$. MAP7 does not increase branch initiation but rather makes a delayed entry into new branches and is associated with increased MT acetylation, suggesting a potential role for MAP7 in MT stabilization and branch maturation ${ }^{61}$. $\beta$-tubulin phosphorylation by Dyrk1a or its Drosophila homolog "minibrain" inhibits tubulin polymerization critical for dendritic branching ${ }^{62}$. Acetylation of $\alpha$-tubulin decreases MT dynamics, thereby regulating axonal branching ${ }^{63}$. In vitro and in vivo studies suggest that murine headless Myo10 contributes to MT stability and is important for branch formation ${ }^{64}$, as its deficiency destabilizes MTs and reduces apical dendrite branching. MT destabilization is a mechanism normally associated with the pruning of axonal arbors required to maintain neuronal networks and eliminate synapses. Destabilization of MTs by the severing protein spastin leads to organelle transport deficits and elimination of specific axon branches ${ }^{65}$. Analogously, downstream of Ube3A/E6AP, MT disruption mediates dendritic arbor shrinkage ${ }^{66}$. Increased 
Ube3A/E6AP expression leads to ubiquitination and degradation of X-linked inhibitor of apoptosis proteins, resulting in the activation of caspase 3 and MT cleavage.

\section{Interaction with the extracellular environment influences branching}

Adhesions formed by a neuron with other cell types or with the extracellular matrix (ECM) promote or restrict arborization by locally initiating signaling cascades that converge on the cytoskeletal machinery and result in stabilization or destabilization of branches ${ }^{67}$. Recent studies strengthen these ideas. "Neuritic adhesion complexes" formed between post-synaptic neuroligin in the muscle membrane and pre-synaptic neurexin, syd-1, and liprin- $\alpha$ of adult Drosophila pleural muscle motoneurons (PM-Mns) promote axonal arborization ${ }^{68}$. Live imaging of this process supported a "stick and grow" mechanism" 6 , contrary to the widely accepted "synaptotropic hypothesis", which suggests synapses promote the growth and stabilization of axonal and dendritic arbors. Other cell adhesion molecules that promote arborization include L1-Cell Adhesion Molecule (L1CAM), Contactin-4 (CNTN4), Negr1, and Dystroglycan (DG). L1CAM functions in complex with Ankyrins B and $G$ to positively regulate axonal and dendritic branching ${ }^{69}$. CNTN4, an axonassociated plasma membrane-anchored cell adhesion molecule, together with amyloid precursor protein (APP), regulates axon branching in the nucleus of the optic tract (NOT) in the accessory optic system ${ }^{70}$. Negr1 is a GPI-anchored adhesion molecule that regulates branching in a manner dependent on the metalloprotease ADAM $10^{71}$. DG similarly positively regulates dendritic arborization in hippocampal neurons via the matrix metalloprotease MMP-972, which initiates signal cascades necessary for branch formation. An in vivo RNAi screen to identify novel cell surface receptors that regulate dendritic branching in class IV dendritic arborization neurons identified the axon guidance receptor $\operatorname{Ret}^{73}$. Ret interacts with integrins to stabilize dendritic adhesions and maintain even F-actin distribution along the length of dendrites.

Adhesive contacts can also restrict branching. Homophilic $\gamma$-PCDH (protocadherin) interactions promote dendritic arborization in the murine cerebral cortex, whereas mismatched homophilic interactions reduce dendritic complexity ${ }^{74}$. This is contrary to $\mathrm{PCDH}$ homophilic interactions leading to repulsionmediated self-avoidance in retinal starburst amacrine cells (SACs), Purkinje cells, or olfactory sensory neurons ${ }^{75-77}$. Neuronal cell shape or variations in signaling pathways in different cell types could explain contrasting outcomes. Enclosure of dendritic regions of Drosophila class IV dendritic arborization sensory neurons by epidermal cells, resulting in a loss of integrin-mediated contact with the ECM, reduces branching in enclosed regions ${ }^{78}$. This is mediated by the epithelial septal junction protein Coracle (Cora) expressed in dendrites and surrounding epidermal cells.

\section{Cellular organelles central to branching}

Neuronal branching increases plasma membrane surface area and cytoplasmic volume. Delivery of organelles such as mitochondria, endoplasmic reticulum (ER), and Golgi outposts to nascent branches facilitates branch growth and maintenance ${ }^{42}$. Recent studies bolster roles for these organelles in branching. Mitochondria provide ATP for branch formation, which fuels actin dynamics ${ }^{79}$. Chondroitin sulfate proteoglycans (CSPGs) disrupt the mitochondrial membrane potential and respiratory potential and thus impair actin dynamics and axon branching ${ }^{80}$. The mitochondrial fission protein GTPase Drp1 is required for dendritic entry of mitochondria. Misregulated expression of Drp1 results in clustering of enlarged mitochondria in the soma and reduced dendritic arborization ${ }^{81}$. The ER synthesizes proteins and lipids and maintains $\mathrm{Ca}^{2+}$ homeostasis, all necessary for branch formation. Golgi outposts (GOPs) function in post-ER trafficking distal to the soma and are essential for acentrosomal MT assembly in dendrites. Golgi vesicles and recycling endocytic vesicles are transported and delivered to the plasma membrane and potentially provide plasma membrane material for branching ${ }^{16,82}$. Indeed, recent mathematical estimations suggest that exocytosis is sufficient to account for plasma membrane expansion in developing neurons ${ }^{16}$. Several recent studies support this: ablation of genes encoding the GTPase Rab10 and members of the exocyst complex, essential for vesicle trafficking and targeting, results in dendritic arborization defects in C. elegans $^{83}$. Impaired GOP synthesis caused by nuclear polyQ-mediated downregulation of COPII secretory pathway genes results in reduced dendritic branching of Drosophila dendritic arborization sensory neurons ${ }^{84}$. Conversely, local endocytosis triggers thinning and pruning of branches ${ }^{85}$.

\section{Transcriptional regulation of branching}

The transcriptional control of gene expression has long been appreciated to regulate neuronal morphogenesis, presumably by converging on cytoskeletal or membrane remodeling ${ }^{36,86-90}$. Recent studies continue to further our understanding of the field. The evolutionarily conserved transcription factor (TF) FoxO regulates dendritic branch initiation and stability in Drosophila dendritic arborization sensory neurons by modulating MT dynamics and anterograde MT growth ${ }^{91}$. Sterol regulatory element binding proteins (SREBPs) are TFs critical for the expression of genes necessary for lipid synthesis ${ }^{92}$. Silencing SREBP expression reduces dendrite length and branching in class IV dendritic arborization neurons in Drosophila ${ }^{93}$. Although glia provide fatty acids for neurite growth ${ }^{94,95}$, this recent study suggests that cell-autonomous fatty acid synthesis is also crucial for neuronal morphogenesis. Calcium responsive element binding protein (CREB) is a $\mathrm{TF}$ that regulates neuronal morphology in an activity-dependent manner ${ }^{96,97}$. A recent study identifies a role for CREB phosphorylation in regulating neuronal architecture in an activity-independent manner during the early stages of neuronal development ${ }^{98}$. Silencing of the TF Sox 5 reduces dendritic branching in Drosophila dendritic arborization sensory neurons, possibly by modulating Wnt signaling ${ }^{99}$. The Pea3 family TFs Etv4 and Etv5 are essential in proper dendritic arborization in hippocampal pyramidal neurons ${ }^{100}$ potentially downstream of BDNF.

Proteins that alter TF function also affect neuronal branching. The nuclear-nucleolar, intrinsically disordered 
protein LAPS18-like protein (mLLP) is a cell-permeable protein induced and secreted upon neuronal activity. When added to culture medium, mLLP enhances dendritic arborization by regulating the function of the TF $\mathrm{CTCF}^{101}$. This raises the possibility that the secretion of mLLP is induced by neuronal activity and it is transferred to other neurons to modulate neuronal structure. The activity-dependent kinase cyclin-dependent kinase 5 (CDK5) regulates dendritic arborization. Upon membrane depolarization, CDK5 translocates to the nucleus, where it phosphorylates and inhibits the activity of the repressive TF methyl-CpG-binding protein $2(\mathrm{MeCP} 2)^{102}$. This leads to the transcriptional activation of $B d n f$ and dendritic arborization.

Chromatin remodeling via DNA methylation and de-methylation, ATP-dependent DNA sliding around the nucleosome, and histone modification modulate gene transcription and neuronal branching patterns ${ }^{103-106}$. Knocking out DNA methyltransferase-3 (DNMT3A) in human embryonic stem cells prior to differentiation into motor neurons decreases dendritic arborization ${ }^{107}$. The Ten-eleven translocation (Tet) family of dioxygenases, which mediate the conversion of 5-methylcytosine $(5 \mathrm{mC})$ on DNA to 5-hydroxymethylcytosine $(5 \mathrm{hmC})^{108}$, also modulate branching. $5 \mathrm{hmC}$ levels are high at exon start sites of multiple genes upregulated during cerebellar circuitry formation, including axon guidance genes. Tet knockdown inhibits dendritic arborization in cerebellar granule cells, suggesting that Tet regulates $5 \mathrm{hmC}$ levels at exon start sites and the transcription of genes regulating dendritic arborization ${ }^{109}$. ARID1B, a member of the SWI/SNF chromatin remodeling complex, is also critical for regulating dendritic arborization in developing pyramidal neurons ${ }^{110}$ and thus synaptic function. Truncating mutations or haploinsufficiency of this gene is associated with the developmental disorder Coffin-Siris syndrome, characterized by intellectual disability and speech impairments, autism spectrum disorders, and associated traits such as reduced weight, hydrocephaly, and impaired motor coordination ${ }^{11-116}$. The histone deacetylase-4 (HDAC4) and the HDAC-interacting protein ankyrin repeat domain containing protein-11 (ANKRD11) regulate dendritic branching ${ }^{117,118}$, indicating that histone acetylation and deacetylation, marks for gene activation and inactivation, respectively, are important players that modulate branching. Both enzymes downregulate the expression of growth factors necessary for morphogenesis. These studies highlight the importance of epigenetic changes in regulating branching morphogenesis and neuronal circuitry.

\section{Post-transcriptional regulation of branching}

Post-transcriptional regulation of gene expression via noncoding microRNAs (miR), alternative splicing, and RNA-binding proteins that alter mRNA conformation are other mechanisms that modulate neuronal branching ${ }^{119,120}$. miRs recently shown to regulate branching morphogenesis include lin-4 miR in C. elegans and miR-9, miR-124, miR-128 and miR-16 in the mammalian nervous system ${ }^{121-124}$. lin-4 and its target mRNA encoding the heterochronic TF LIN-14 modulate axonal branching in the PLM neuron in C. elegans. miR-9, miR-124, and miR-16 and their target proteins alter dendritic branching by functioning upstream of signaling pathways such as the Akt/GSK3 $\beta$ or MAPK/ERK pathways. Alternative splicing factors such as Caper and RNA-binding Fox1 (Rbfox1) are examples that alternative splicing influences branching ${ }^{125,126}$. Caper negatively regulates branching of class IV dendritic arborization neurons in flies by directly or indirectly regulating the expression of over 500 genes, whereas Rbfox 1 isoform 2 contributes to dendritic branching by an unknown mechanism. Other RNA-binding proteins that regulate branching include the RNA helicase Moloney leukemia virus 10 (Mov10) ${ }^{127}$. Cytoplasmic Mov10 possibly renders mRNA, mostly coding for cytoskeletal proteins critical for neuronal morphogenesis, accessible to the RNAinduced silencing complex (RISC) or miRNA-guided cleavage.

mRNA translation also affects arborization and is regulated globally throughout the neuron and locally in the axon or the dendrite $^{120,128}$. Density regulated protein (DENR) mediates translation re-initiation after long open reading frames. Overexpression or knockdown of DENR in murine cortical neurons altered spatial dendritic complexity, in particular proximal to the cell body. Furthermore, expression of de novo missense mutations identified in two unrelated patients with brain developmental disorder disrupted the function of DENR on mRNA translation re-initiation and the terminal branching of cortical neurons. This suggests DENR's role in mRNA translation is critical to branching morphogenesis ${ }^{129}$. The classic translational repressors Nanos (Nos) ${ }^{130}$ and Pumilio (Pum) repress the expression of the pro-apoptotic gene head involution defective (hid) ${ }^{131}$ and maintain a balance between outgrowth and retraction of dendrites and branches. In contrast, when Hid is upregulated, non-apoptotic caspase activation leads to dendritic arbor pruning. Zipcode binding protein 1 (ZBP1) is a component of the mRNA-binding ribonucleoprotein particle that controls local translation of $\beta$-actin mRNA ${ }^{132}$. ZBP1 binding represses $\beta$-actin mRNA translation and ensures proper distribution to sites of local synthesis, where repression is reversed by Y396 phosphorylation on ZBP1. mTORC2, Src, and mRNA binding-dependent S181 phosphorylation of ZBP1 is essential for ZBP1 mobility and distribution along dendrites and regulation of dendritic branching in hippocampal neurons ${ }^{133}$. An unbiased genome-wide screen identified 55 new candidate mRNA transcripts that localize specifically to dendrites of Drosophila class IV dendritic arborization sensory neurons ${ }^{134}$. Further validation identified 18 genes whose mRNA is transported specifically to dendrites for local translation and regulation of branching. These pathways are likely also relevant in vivo in mammals; recent evidence demonstrates that mRNA, and in particular actin mRNA, is transported to docking sites, and subsequent local protein synthesis hotspots in the retinal ganglion axon in vivo, and that these sites overlap with branch initiation sites. Thus, sites of local translation may serve as branch initiation sites and regulate branch numbers ${ }^{135}$.

\section{Enzymatic activity modulates branching}

Various enzymes and PTMs that regulate signaling cascades modulate neuronal branching by directly or indirectly influencing cytoskeletal dynamics and plasma membrane addition ${ }^{128,136-140}$. 
Recent studies attribute novel roles for numerous enzymes during branching morphogenesis. The methylase coactivatorassociated arginine methyltransferase 1 (CARM1) localizes to post-synaptic densities (PSDs) in hippocampal neurons, and CARM1 knockdown leads to exuberant dendritic branching and increased spine density ${ }^{141}$. CARM1 may function by methylating $\mathrm{HuD}$, an mRNA-binding protein, which prevents $\mathrm{HuD}$ from binding and stabilizing mRNA, thereby regulating the expression of proteins directly required for dendrite maturation, such as BDNF. Alternatively, CARM1 may methylate substrates containing an RXR motif and alter protein-protein interactions in the PSD or regulate the expression of downstream proteins such as GTPases and actin regulators ${ }^{141}$. Methylation via CARM1 downregulates synaptic gene expression and controls neuronal differentiation ${ }^{142}$, but whether these pathways function in branching has not been shown. PRMT8 is a brain enriched plasma membrane-anchored methyltransferase and phospholipase that promotes dendritic branching. $\mathrm{Prmt}^{-/}$mice exhibit reduced dendritic complexity in cerebellar Purkinje cells ${ }^{143}$. Auto-methylation regulates PRMT8 activity; however, PRMT8 is not known to methylate other substrates proximal to the membrane. PRMT8 does, however, mediate the hydrolysis of phosphatidic choline (PC) to choline and phosphatidic acid (PA). Since PA is a precursor for the synthesis of other phospholipids, PRMT8 may alter the composition and biophysical properties of membranes during axonal and dendritic morphogenesis.

Phosphorylation- and ubiquitination-mediated modulation of signaling plays an important role in neuronal development. For example, activation of the non-receptor tyrosine kinase FAK is required for netrin-dependent cortical axon branching ${ }^{144}$. In the absence of netrin, the E3 ubiquitin ligase tripartite motif protein 9 (TRIM9) impairs this phosphorylation and activation of FAK via nondegradative ubiquitination of the netrin receptor DCC. Ubiquitination reduces DCC binding to FAK and inhibits subsequent FAK activation. In the presence of netrin-1, TRIM9-mediated ubiquitination of DCC drops, leading to FAK activation, increased exocytosis, and a concomitant increase in axonal branching. TRIM9 negatively regulates axon branching and dendritic arborization in cortical and hippocampal neurons as well ${ }^{145,146}$. In contrast to axons, FAK activity negatively regulates dendritic arborization. FAK activation can be inhibited by $\gamma$-Pcdh, which binds and inhibits FAK activation ${ }^{147}$, and thus increases dendritic arborization ${ }^{148}$. When $\mathrm{S} 922$ of $\gamma$-Pcdh is phosphorylated by PKC, inhibition of FAK does not occur, ultimately resulting in reduced dendritic arborization in cortical neurons ${ }^{149}$. Recent studies exploring gene copy number variations such as $16 \mathrm{p} 11.2$ microduplication and layer-specific requirements of the ERK/MAPK signaling pathways during neocortical development continue to highlight the importance of the ERK/MAPK signaling pathways in modulating neuronal arborization $^{150,151}$.

Dephosphorylation similarly modulates branching, and recent examples demonstrate that localized signaling cascades exert spatial control of branching via dephosphorylation. Straitin-1, a subunit of the $\mathrm{S} / \mathrm{T}$ phosphatase $\mathrm{PP} 2 \mathrm{~A}$, is enriched in striatal neurons, where it negatively regulates dendritic complexity, surprisingly without influencing synaptic connectivity or neuronal $\operatorname{activity}^{152}$. Protein tyrosine phosphatase $\delta$ (PTP $\delta$ ) dephosphorylates and activates Fyn and Src kinases downstream of the repulsive guidance molecule Semaphorin-3A (Sema3A), resulting in increased cortical basal dendritic arborization ${ }^{153}$. The receptor protein tyrosine phosphatase-69D (RPTP69D) dephosphorylates the cell adhesion molecule DSCAM downstream of Slit ${ }^{154}$, which promotes the extension of collateral axonal branches.

\section{Neuronal activity influences branching}

Neuronal activity influences branching by regulating calcium activity or inducing transcriptional changes that alter the expression of adhesion molecules, neurotransmitters, growth factors, etc. ${ }^{155}$. Recent studies support the hypothesis that neuronal activity directly influences branching. When neuronal activity increases, axonal branches in thalamocortical neurons arise from non-synaptic sites ${ }^{156}$. How activity initiates non-synaptic branch points is not known, but it likely promotes the recruitment of actin-polymerizing factors and other machinery involved in branching to these nascent sites. KIBRA (Kidney and Brain, also known as WWC1) is a somatodendritic phosphoprotein primarily expressed in the hippocampus and cerebral cortex, regions where activity-dependent structural plasticity are critical in memory formation ${ }^{157-160}$. KIBRA colocalizes and interacts with GluA1 along dendrites, where it regulates recycling and surface levels of GluA1-containing AMPA receptors and thus activity. Overexpression of KIBRA increases the recycling of GluA1containing AMPA receptors and also increases the number of branch points along dendrites of murine pyramidal neurons ${ }^{161}$. Although GluA1 is also known to alter dendritic morphology ${ }^{162}$, whether KIBRA regulates dendritic branching via GluA1 is unknown.

There is growing evidence that neuronal activity indirectly contributes to branching via the regulation of gene expression. Neuritin is a cell surface-anchored protein upregulated by elevated neuronal activity, such as synchronous firing from an epileptic focus. Neuritin promotes aberrant mossy fiber sprouting of hippocampal granule neurons in vivo ${ }^{163}$, which exacerbates seizure activity. Neuritin overexpression in dissociated hippocampal granule neurons also promotes axonal branching by cooperatively acting with fibroblast growth factor-4 (FGF-4) to recruit FGF receptor (FGFR) and activating the canonical signaling pathway downstream of FGFR. This novel mechanism could contribute to the identification of therapeutic targets for the treatment of epileptic seizures.

\section{Conclusion}

Recent advances in understanding branching morphogenesis have provided insights into activity-dependent and activityindependent extracellular and intrinsic factors that regulate axonal and dendritic branch formation, maintenance, and pruning. The studies reviewed here along with research over the past four decades highlight the complexity of the regulation of 
neuronal branching. It is evident that cross-talk between pathways operating in parallel regulate branching and fundamental questions remain to be addressed. This includes how signaling pathways and molecules are spatially compartmentalized along the axon and the dendrites, how branches arise from specific points along the axon and dendrite, and how various signaling pathways are coordinated to regulate branching in a temporally and spatially controlled manner.

\section{Grant information}

This work was supported in part by the National Institute of General Medical Sciences (GM108970).

The funders had no role in study design, data collection and analysis, decision to publish, or preparation of the manuscript.

Acknowledgements

We thank Jason Toussaint for graphic design assistance.
1. Harris SD: Branching of fungal hyphae: regulation, mechanisms and comparison with other branching systems. Mycologia. 2008; 100(6): 823-32. PubMed Abstract | Publisher Full Text

2. Iber D, Menshykau D: The control of branching morphogenesis. Open Biol. 2013; 3(9): 130088

PubMed Abstract | Publisher Full Text | Free Full Text

3. Lu P, Werb Z: Patterning mechanisms of branched organs. Science. 2008; 322(5907): 1506-9.

PubMed Abstract | Publisher Full Text | Free Full Text

4. Ochoa-Espinosa A, Affolter M: Branching morphogenesis: from cells to organs and back. Cold Spring Harb Perspect Biol. 2012; 4(10): pii: a008243.

PubMed Abstract | Publisher Full Text | Free Full Text

5. Kulkarni VA, Firestein BL: The dendritic tree and brain disorders. Mol Cell Neurosci. 2012; 50(1): 10-20.

PubMed Abstract | Publisher Full Text

6. Copf T: Impairments in dendrite morphogenesis as etiology for neurodevelopmental disorders and implications for therapeutic treatments. Neurosci Biobehav Rev. 2016; 68: 946-78. PubMed Abstract | Publisher Full Text

7. Kern JK, Geier DA, King PG, et al:: Shared Brain Connectivity Issues, Symptoms, and Comorbidities in Autism Spectrum Disorder, Attention Deficit/ Hyperactivity Disorder, and Tourette Syndrome. Brain Connect. 2015; 5(6): 321-35.

PubMed Abstract | Publisher Full Text

8. Anderson JS, Druzgal TJ, Froehlich A, et al.: Decreased interhemispheric functional connectivity in autism. Cereb Cortex. 2011; 21(5): 1134-46. PubMed Abstract | Publisher Full Text | Free Full Text

9. Zikopoulos $\mathrm{B}$, Barbas $\mathrm{H}$ : Changes in prefrontal axons may disrupt the network in autism. $J$ Neurosci. 2010; 30(44): 14595-609. PubMed Abstract | Publisher Full Text | Free Full Text

10. Zikopoulos B, Barbas $\mathrm{H}$ : Altered neural connectivity in excitatory and inhibitory cortical circuits in autism. Front Hum Neurosci. 2013; 7: 609. PubMed Abstract | Publisher Full Text | Free Full Text

11. Pfenninger KH: Plasma membrane expansion: a neuron's Herculean task. Nat Rev Neurosci. 2009; 10(4): 251-61. PubMed Abstract | Publisher Full Tex

12. Gallo G: The cytoskeletal and signaling mechanisms of axon collateral branching. Dev Neurobiol. 2011; 71(3): 201-20. PubMed Abstract | Publisher Full Text

13. Pacheco A, Gallo G: Actin filament-microtubule interactions in axon initiation and branching. Brain Res Bull. 2016; 126(Pt 3): 300-10 PubMed Abstract | Publisher Full Text | Free Full Text

14. Konietzny A, Bär J, Mikhaylova M: Dendritic Actin Cytoskeleton: Structure, Functions, and Regulations. Front Cell Neurosci. 2017; 11: 147. PubMed Abstract | Publisher Full Text | Free Full Text

15. Delandre C, Amikura R, Moore AW: Microtubule nucleation and organization in dendrites. Cell Cycle. 2016; 15(13): 1685-92. PubMed Abstract | Publisher Full Text | Free Full Text

16. F Urbina FL, Gomez SM, Gupton SL: Spatiotemporal organization of exocytosis emerges during neuronal shape change. J Cell Biol. 2018; 217(3) 1113-28.

PubMed Abstract | Publisher Full Text | Free Full Text | F1000 Recommendation

17. Ros $\mathrm{O}$, Cotrufo $\mathrm{T}$, Martínez-Mármol R, et al:: Regulation of patterned dynamics of local exocytosis in growth cones by netrin-1. J Neurosci. 2015; 35(13): 5156-70. PubMed Abstract | Publisher Full Text

18. $\mathrm{F}$ Tojima $\mathrm{T}$, Akiyama $\mathrm{H}$, Itofusa $\mathrm{R}$, et al:: Attractive axon guidance involves asymmetric membrane transport and exocytosis in the growth cone. Nat Neurosci. 2007; 10(1): 58-66.

PubMed Abstract | Publisher Full Text | F1000 Recommendation
19. Ka M, Jung EM, Mueller U, et al.: MACF1 regulates the migration of pyramidal neurons via microtubule dynamics and GSK-3 signaling. Dev Biol. 2014; 395(1): 4-18. PubMed Abstract | Publisher Full Text | Free Full Text

20. Ka M, Kim WY: Microtubule-Actin Crosslinking Factor 1 Is Required for Dendritic Arborization and Axon Outgrowth in the Developing Brain. Mol Neurobiol. 2016; 53(9): 6018-32.

PubMed Abstract | Publisher Full Text | Free Full Text

21. Coles $\mathrm{CH}$, Bradke $\mathrm{F}$ : Coordinating neuronal actin-microtubule dynamics. Curr Biol. 2015; 25(15): R677-91.

PubMed Abstract | Publisher Full Text

22. F Xu K, Zhong G, Zhuang X: Actin, spectrin, and associated proteins form a periodic cytoskeletal structure in axons. Science. 2013; 339(6118): 452-6. PubMed Abstract | Publisher Full Text | Free Full Text | F1000 Recommendation

23. F Ganguly A, Tang $Y$, Wang $L$, et al:: A dynamic formin-dependent deep F-actin network in axons. J Cell Biol. 2015; 210(3): 401-17. PubMed Abstract | Publisher Full Text | Free Full Text | F1000 Recommendation

24. Ladt K, Ganguly A, Roy S: Axonal actin in action: Imaging actin dynamics in neurons. Methods Cell Biol. 2016; 131: 91-106.

PubMed Abstract | Publisher Full Text

25. Baas PW, Deitch JS, Black MM, et al:: Polarity orientation of microtubules in hippocampal neurons: uniformity in the axon and nonuniformity in the dendrite. Proc Natl Acad Sci U S A. 1988; 85(21): 8335-9.

PubMed Abstract | Publisher Full Text | Free Full Text

26. Yau KW, Schätzle P, Tortosa E, et al:: Dendrites In Vitro and In Vivo Contain Microtubules of Opposite Polarity and Axon Formation Correlates with Uniform Plus-End-Out Microtubule Orientation. J Neurosci. 2016; 36(4): 1071-85. PubMed Abstract | Publisher Full Text | Free Full Text

27. Conde $\mathrm{C}$, Cáceres A: Microtubule assembly, organization and dynamics in axons and dendrites. Nat Rev Neurosci. 2009; 10(5): 319-32. PubMed Abstract | Publisher Full Text

28. Kollins KM, Bell RL, Butts $\mathrm{M}$, et al: Dendrites differ from axons in patterns of microtubule stability and polymerization during development. Neural Dev. 2009; 4: 26.

PubMed Abstract | Publisher Full Text | Free Full Text

29. Kwan AC, Dombeck DA, Webb WW: Polarized microtubule arrays in apical dendrites and axons. Proc Natl Acad Sci U S A. 2008; 105(32): 11370-5. PubMed Abstract | Publisher Full Text | Free Full Text

30. Georges PC, Hadzimichalis NM, Sweet ES, et al:: The yin-yang of dendrite morphology: unity of actin and microtubules. Mol Neurobiol. 2008; 38(3): 270-84. PubMed Abstract | Publisher Full Text

31. Stone MC, Roegiers F, Rolls MM: Microtubules have opposite orientation in axons and dendrites of Drosophila neurons. Mol Biol Cell. 2008; 19(10): 4122-9. PubMed Abstract | Publisher Full Text | Free Full Text

32. Tas RP, Chazeau A, Cloin BMC, et al.: Differentiation between Oppositely Oriented Microtubules Controls Polarized Neuronal Transport. Neuron. 2017; 96(6): 1264-1271.e5

PubMed Abstract | Publisher Full Text | Free Full Text

33. Armijo-Weingart L, Gallo G: It takes a village to raise a branch: Cellular mechanisms of the initiation of axon collateral branches. Mol Cell Neurosci. 2017; 84: 36-47.

PubMed Abstract | Publisher Full Text | Free Full Text

34. Copf $\mathrm{T}$ : Importance of gene dosage in controlling dendritic arbor formation during development. Eur J Neurosci. 2015; 42(6): 2234-49. PubMed Abstract | Publisher Full Text

35. $\mathrm{F}$ Cuntz $\mathrm{H}$, Forstner $\mathrm{F}$, Borst $\mathrm{A}$, et al.: One rule to grow them all: a general theory of neuronal branching and its practical application. PLoS Comput Biol. 2010; 6(8): pii: e1000877.

PubMed Abstract | Publisher Full Text | Free Full Text | F1000 Recommendation 
36. Jan YN, Jan LY: Branching out: mechanisms of dendritic arborization. Nat Rev Neurosci. 2010; 11(5): 316-28.

PubMed Abstract | Publisher Full Text | Free Full Text

37. Kalil K, Dent EW: Branch management: mechanisms of axon branching in the developing vertebrate CNS. Nat Rev Neurosci. 2014; 15(1): 7-18. PubMed Abstract | Publisher Full Text | Free Full Text

38. Keeler AB, Molumby MJ, Weiner JA: Protocadherins branch out: Multiple roles in dendrite development. Cell Adh Migr. 2015; 9(3): 214-26. PubMed Abstract | Publisher Full Text | Free Full Text

39. Ledda F, Paratcha G: Mechanisms regulating dendritic arbor patterning. Cell Mol Life Sci. 2017; 74(24): 4511-37.

PubMed Abstract | Publisher Full Tex

40. Lefebvre JL, Sanes JR, Kay JN: Development of dendritic form and function. Annu Rev Cell Dev Biol. 2015; 31: 741-77.

PubMed Abstract | Publisher Full Tex

41. Wang Y, Li WY, Li ZG, et al.: Transcriptional and Epigenetic Regulation in Injury-Mediated Neuronal Dendritic Plasticity. Neurosci Bull. 2017; 33(1): 85-94. PubMed Abstract | Publisher Full Text | Free Full Text

42. Winkle CC, Taylor KL, Dent EW, et al.: Beyond the cytoskeleton: The emerging role of organelles and membrane remodeling in the regulation of axon collateral branches. Dev Neurobiol. 2016; 76(12): 1293-307. PubMed Abstract | Publisher Full Text | Free Full Text

43. Wong ROL, Ghosh A: Activity-dependent regulation of dendritic growth and patterning. Nat Rev Neurosci. 2002; 3(10): 803-12. PubMed Abstract | Publisher Full Text

44. Heiman MG, Shaham S: Twigs into branches: how a filopodium becomes a dendrite. Curr Opin Neurobiol. 2010; 20(1): 86-91. PubMed Abstract | Publisher Full Text | Free Full Text

45. Menon S, Gupton SL: Building Blocks of Functioning Brain: Cytoskeletal Dynamics in Neuronal Development. Int Rev Cell Mol Biol. 2016; 322: 183-245. PubMed Abstract | Publisher Full Text | Free Full Text

46. Winkle CC, Gupton SL: Membrane Trafficking in Neuronal Development: Ins and Outs of Neural Connectivity. Int Rev Cell Mol Biol. 2016; 322: 247-80. PubMed Abstract | Publisher Full Text | Free Full Text

47. Acebes A, Ferrús A: Cellular and molecular features of axon collaterals and dendrites. Trends Neurosci. 2000; 23(11): 557-65. PubMed Abstract | Publisher Full Text

48. Giolli RA, Towns LC: A review of axon collateralization in the mammalian visua system. Brain Behav Evol. 1980; 17(5): 364-90.

PubMed Abstract | Publisher Full Text

49. Mitchison G: Axonal trees and cortical architecture. Trends Neurosci. 1992; 15(4): 122-6.

PubMed Abstract | Publisher Full Text

50. F Leung KM, van Horck FPG, Lin AC, et al:: Asymmetrical beta-actin mRNA translation in growth cones mediates attractive turning to netrin-1. Nat Neurosci. 2006; 9(10): 1247-56.

PubMed Abstract | Publisher Full Text | Free Full Text | F1000 Recommendation

51. Bassell GJ, Zhang H, Byrd AL, et al:: Sorting of beta-actin mRNA and protein to neurites and growth cones in culture. J Neurosci. 1998; 18(1): 251-65. PubMed Abstract | Publisher Full Text

52. Moradi M, Sivadasan R, Saal L, et al:: Differential roles of $\alpha-, \beta-$, and $\gamma$-actin in axon growth and collateral branch formation in motoneurons. J Cell Biol. 2017; 216(3): 793-814.

PubMed Abstract | Publisher Full Text | Free Full Text

53. Spillane M, Ketschek A, Jones SL, et al.: The actin nucleating Arp2/3 complex contributes to the formation of axonal filopodia and branches through the regulation of actin patch precursors to filopodia. Dev Neurobiol. 2011; 71(9): $747-58$

PubMed Abstract | Publisher Full Text | Free Full Text

54. $\mathrm{F}$ Chen $\mathrm{CH}, \mathrm{He} \mathrm{CW}$, Liao $\mathrm{CP}$, et al:: A Wnt-planar polarity pathway instructs neurite branching by restricting $F$-actin assembly through endosomal signaling. PLOS Genet. 2017; 13(4): e1006720.

PubMed Abstract | Publisher Full Text | Free Full Text | F1000 Recommendation

55. Nithianandam V, Chien CT: Actin blobs prefigure dendrite branching sites. J Cell Biol. 2018: 217(10): 3731-46.

PubMed Abstract | Publisher Full Text | Free Full Text

56. F Zou W, Dong X, Broederdorf TR, et al:: A Dendritic Guidance Receptor Complex Brings Together Distinct Actin Regulators to Drive Efficient F-Actin Assembly and Branching. Dev Cell. 2018; 45(3): 362-375.e3. PubMed Abstract | Publisher Full Text | F1000 Recommendation

57. F Avery AW, Thomas DD, Hays TS: $\beta$-III-spectrin spinocerebellar ataxia type 5 mutation reveals a dominant cytoskeletal mechanism that underlies dendritic arborization. Proc Natl Acad Sci U S A. 2017; 114(44): E9376-E9385. PubMed Abstract | Publisher Full Text | Free Full Text | F1000 Recommendation

58. Kapitein LC, Hoogenraad CC: Building the Neuronal Microtubule Cytoskeleton. Neuron. 2015; 87(3): 492-506.

PubMed Abstract | Publisher Full Tex

59. Tian G, Huang $Y$, Rommelaere $H$, et al:: Pathway leading to correctly folded beta-tubulin. Cell. 1996; 86(2): 287-96. PubMed Abstract | Publisher Full Text

60. Okumura M, Sakuma $\mathrm{C}$, Miura M, et al.: Linking cell surface receptors to microtubules: tubulin folding cofactor $D$ mediates Dscam functions during neuronal morphogenesis. J Neurosci. 2015; 35(5): 1979-90.

PubMed Abstract | Publisher Full Text

61. F Tymanskyj SR, Yang B, Falnikar A, et al:: MAP7 Regulates Axon Collateral Branch Development in Dorsal Root Ganglion Neurons. J Neurosci. 2017; 37(6): $1648-61$

PubMed Abstract | Publisher Full Text | Free Full Text | F1000 Recommendation

62. Ori-McKenney KM, McKenney RJ, Huang HH, et al:: Phosphorylation of $\beta$-Tubulin by the Down Syndrome Kinase, Minibrain/DYRK1a, Regulates Microtubule Dynamics and Dendrite Morphogenesis. Neuron. 2016; 90(3): 551-63. PubMed Abstract | Publisher Full Text | Free Full Text

63. F Dan W, Gao N, Li L, et al:: $\alpha$-Tubulin Acetylation Restricts Axon Overbranching by Dampening Microtubule Plus-End Dynamics in Neurons. Cereb Cortex. 2018; 28(9): 3332-46.

PubMed Abstract | Publisher Full Text | F1000 Recommendation

64. Yu H, Sun D, Wang $\mathrm{N}$, et al.: Headless Myo10 is a regulator of microtubule stability during neuronal development. J Neurochem. 2015; 135(2): 261-73. PubMed Abstract | Publisher Full Text

65. F Brill MS, Kleele T, Ruschkies L, et al: Branch-Specific Microtubule Destabilization Mediates Axon Branch Loss during Neuromuscular Synapse Elimination. Neuron. 2016; 92(4): 845-56.

PubMed Abstract | Publisher Full Text | Free Full Text | F1000 Recommendation

66. F Khatri N, Gilbert JP, Huo Y, et al:: The Autism Protein Ube3A/E6AP Remodels Neuronal Dendritic Arborization via Caspase-Dependent Microtubule Destabilization. J Neurosci. 2018; 38(2): 363-78

PubMed Abstract | Publisher Full Text | Free Full Text | F1000 Recommendation

67. Leshchyns'ka I, Sytnyk V: Reciprocal Interactions between Cell Adhesion Molecules of the Immunoglobulin Superfamily and the Cytoskeleton in Neurons. Front Cell Dev Biol. 2016; 4: 9

PubMed Abstract | Publisher Full Text | Free Full Text

68. F Constance WD, Mukherjee A, Fisher YE, et al:: Neurexin and Neuroliginbased adhesion complexes drive axonal arborisation growth independent of synaptic activity. eLife. 2018; 7: pii: e31659.

PubMed Abstract | Publisher Full Text | Free Full Text | F1000 Recommendation

69. Patzke C, Acuna C, Giam LR, et al.: Conditional deletion of L1CAM in human neurons impairs both axonal and dendritic arborization and action potential generation. J Exp Med. 2016; 213(4): 499-515.

PubMed Abstract | Publisher Full Text | Free Full Text

70. Osterhout JA, Stafford BK, Nguyen PL, et al:: Contactin-4 mediates axon-target specificity and functional development of the accessory optic system. Neuron. 2015; 86(4): 985-99.

PubMed Abstract | Publisher Full Text | Free Full Text

71. Pischedda F, Piccoli G: The IgLON Family Member Negr1 Promotes Neuronal Arborization Acting as Soluble Factor via FGFR2. Front Mol Neurosci. 2016; 8: 89 PubMed Abstract | Publisher Full Text | Free Full Text

72. Bijata M, Wlodarczyk J, Figiel I: Dystroglycan controls dendritic morphogenesis of hippocampal neurons in vitro. Front Cell Neurosci. 2015; 9: 199. PubMed Abstract | Publisher Full Text | Free Full Text

73. Soba $\mathrm{P}$, Han $\mathrm{C}$, Zheng $\mathrm{Y}$, et al:: The Ret receptor regulates sensory neuron dendrite growth and integrin mediated adhesion. eLife. 2015; 4: e05491. PubMed Abstract | Publisher Full Text | Free Full Text

74. F Molumby MJ, Keeler AB, Weiner JA: Homophilic Protocadherin Cell-Cell Interactions Promote Dendrite Complexity. Cell Rep. 2016; 15(5): 1037-50. PubMed Abstract | Publisher Full Text | Free Full Text | F1000 Recommendation

75. Kostadinov D, Sanes JR: Protocadherin-dependent dendritic self-avoidance regulates neural connectivity and circuit function. eLife. 2015; 4: e08964. PubMed Abstract | Publisher Full Text | Free Full Text

76. Lefebvre JL, Kostadinov D, Chen WV, et al:: Protocadherins mediate dendritic self-avoidance in the mammalian nervous system. Nature. 2012; 488(7412): $517-521$

PubMed Abstract | Publisher Full Text | Free Full Text

77. F Mountoufaris G, Chen WV, Hirabayashi Y, et al.: Multicluster Pcdh diversity is required for mouse olfactory neural circuit assembly. Science. 2017; 356(6336): 411-4

PubMed Abstract | Publisher Full Text | Free Full Text | F1000 Recommendation

78. Tenenbaum CM, Misra M, Alizzi RA, et al.: Enclosure of Dendrites by Epidermal Cells Restricts Branching and Permits Coordinated Development of Spatially Overlapping Sensory Neurons. Cell Rep. 2017; 20(13): 3043-56. PubMed Abstract | Publisher Full Text | Free Full Text

79. Spillane M, Ketschek A, Merianda TT, et al:: Mitochondria coordinate sites of axon branching through localized intra-axonal protein synthesis. Cell Rep. 2013; 5(6): 1564-75

PubMed Abstract | Publisher Full Text | Free Full Text

80. F Sainath $R$, Ketschek A, Grandi L, et al.: CSPGs inhibit axon branching by impairing mitochondria-dependent regulation of actin dynamics and axonal translation. Dev Neurobiol. 2017; 77(4): 454-73.

PubMed Abstract | Publisher Full Text | Free Full Text | F1000 Recommendation

81. Fukumitsu K, Hatsukano T, Yoshimura A, et al:: Mitochondrial fission protein Drp1 regulates mitochondrial transport and dendritic arborization in cerebella Purkinje cells. Mol Cell Neurosci. 2016; 71: 56-65. PubMed Abstract | Publisher Full Text 
82. F Satoh D, Sato D, Tsuyama T, et al.: Spatial control of branching within dendritic arbors by dynein-dependent transport of Rab5-endosomes. Nat $\mathrm{Cell}$ Biol. 2008; 10(10): 1164-71.

PubMed Abstract | Publisher Full Text | F1000 Recommendation

83. Zou W, Yadav S, DeVault L, et al:: RAB-10-Dependent Membrane Transport Is Required for Dendrite Arborization. PLoS Genet. 2015; 11(9): e1005484. PubMed Abstract | Publisher Full Text | Free Full Text

84. F Chung CG, Kwon MJ, Jeon KH, et al:: Golgi Outpost Synthesis Impaired by Toxic Polyglutamine Proteins Contributes to Dendritic Pathology in Neurons. Cell Rep. 2017; 20(2): 356-69.

PubMed Abstract | Publisher Full Text | F1000 Recommendation

85. Kanamori T, Yoshino J, Yasunaga $\mathrm{K}$, et al:: Local endocytosis triggers dendritic thinning and pruning in Drosophila sensory neurons. Nat Commun. 2015; 6: 6515

PubMed Abstract | Publisher Full Text

86. Santiago C, Bashaw GJ: Transcription factors and effectors that regulate neuronal morphology. Development. 2014; 141(24): 4667-80. PubMed Abstract | Publisher Full Text | Free Full Text

87. Volovitch M, Le Roux I, Joliot AH, et al.: Control of neuronal morphogenesis by homeoproteins: consequences for the making of neuronal networks. Perspect Dev Neurobiol. 1993; 1(3): 133-8.

PubMed Abstract

88. Caroni P: Intrinsic neuronal determinants that promote axonal sprouting and elongation. Bioessays. 1997; 19(9): 767-75.

PubMed Abstract | Publisher Full Text

89. Gao FB, Bogert BA: Genetic control of dendritic morphogenesis in Drosophila. Trends Neurosci. 2003; 26(5): 262-8.

PubMed Abstract | Publisher Full Tex

90. de la Torre-Ubieta L, Bonni A: Transcriptional regulation of neuronal polarity and morphogenesis in the mammalian brain. Neuron. 2011; 72(9): 22-40. PubMed Abstract | Publisher Full Text | Free Full Text

91. Sears $\mathrm{JC}$, Broihier $\mathrm{HT}$ : FoxO regulates microtubule dynamics and polarity to promote dendrite branching in Drosophila sensory neurons. Dev Biol. 2016: 418(1): 40-54.

PubMed Abstract | Publisher Full Text | Free Full Text

92. F Seegmiller AC, Dobrosotskaya I, Goldstein JL, et al:: The SREBP pathway in Drosophila: regulation by palmitate, not sterols. Dev Cell. 2002; 2(12): 229-38. PubMed Abstract | Publisher Full Text | F1000 Recommendation

93. F Ziegler AB, Thiele C, Tenedini F, et al:: Cell-Autonomous Control of Neuronal Dendrite Expansion via the Fatty Acid Synthesis Regulator SREBP. Cell Rep. 2017; 21(9): 3346-53.

PubMed Abstract | Publisher Full Text | F1000 Recommendation

94. Nieweg K, Schaller H, Pfrieger FW: Marked differences in cholesterol synthesis between neurons and glial cells from postnatal rats. J Neurochem. 2009; 109(1): 125-34.

PubMed Abstract | Publisher Full Text

95. Rodríguez-Rodríguez RA, Tabernero A, Velasco A, et al.: The neurotrophic effec of oleic acid includes dendritic differentiation and the expression of the neuronal basic helix-loop-helix transcription factor NeuroD2. J Neurochem. 2004; 88(5): 1041-51

PubMed Abstract | Publisher Full Tex

96. Mayr B, Montminy M: Transcriptional regulation by the phosphorylationdependent factor CREB. Nat Rev Mol Cell Biol. 2001; 2(8): 599-609. PubMed Abstract | Publisher Full Text

97. Redmond L, Kashani AH, Ghosh A: Calcium regulation of dendritic growth via CaM kinase IV and CREB-mediated transcription. Neuron. 2002; 34(6): 999-1010. PubMed Abstract | Publisher Full Text

98. F Landeira BS, Santana TTDS, Araújo JAM, et al.: Activity-Independent Effects of CREB on Neuronal Survival and Differentiation during Mouse Cerebral Cortex Development. Cereb Cortex. 2018; 28(2): 538-48. PubMed Abstract | Publisher Full Text | F1000 Recommendation

99. F Li A, Hooli B, Mullin K, et al.: Silencing of the Drosophila ortholog of SOX5 leads to abnormal neuronal development and behavioral impairment. Hum Mol Genet. 2017; 26(8): 1472-82.

PubMed Abstract | Publisher Full Text | Free Full Text | F1000 Recommendation

100. F Fontanet PA, Ríos AS, Alsina FC, et al:: Pea3 Transcription Factors, Etv4 and Etv5, Are Required for Proper Hippocampal Dendrite Development and Plasticity. Cereb Cortex. 2018; 28(9): 236-49.

PubMed Abstract | Publisher Full Text | F1000 Recommendation

101. Yu NK, Kim HF, Shim J, et al.: A transducible nuclear/nucleolar protein, mLLP, regulates neuronal morphogenesis and synaptic transmission. Sci Rep. 2016 6: 22892.

PubMed Abstract | Publisher Full Text | Free Full Text

102. Liang Z, Ye T, Zhou X, et al.: Cdk5 Regulates Activity-Dependent Gen Expression and Dendrite Development. J Neurosci. 2015; 35(45): 15127-34. PubMed Abstract | Publisher Full Text

103. Lilja T, Heldring N, Hermanson O: Like a rolling histone: epigenetic regulation of neural stem cells and brain development by factors controlling histone acetylation and methylation. Biochim Biophys Acta. 2013; 1830(2): 2354-60. PubMed Abstract | Publisher Full Text

104. Jaworska J, Ziemka-Nalecz M, Zalewska T: Histone deacetylases 1 and 2 are required for brain development. Int J Dev Biol. 2015; 59(4-6): 171-7. PubMed Abstract | Publisher Full Text

105. Yoo AS, Crabtree GR: ATP-dependent chromatin remodeling in neural development. Curr Opin Neurobiol. 2009; 19(2): 120-6. PubMed Abstract | Publisher Full Text | Free Full Text

106. López AJ, Wood MA: Role of nucleosome remodeling in neurodevelopmental and intellectual disability disorders. Front Behav Neurosci. 2015; 9: 100. PubMed Abstract | Publisher Full Text | Free Full Text

107. Ziller MJ, Ortega JA, Quinlan KA, et al:: Dissecting the Functional Consequences of De Novo DNA Methylation Dynamics in Human Motor Neuron Differentiation and Physiology. Cell Stem Cell. 2018; 22(4): 559-574.e9. PubMed Abstract | Publisher Full Text

108. F Tahiliani M, Koh KP, Shen $\mathrm{Y}$, et al: Conversion of 5-methylcytosine to 5hydroxymethylcytosine in mammalian DNA by MLL partner TET1. Science. 2009; 324(5929): 930-5.

PubMed Abstract | Publisher Full Text | Free Full Text | F1000 Recommendation

109. F Zhu X, Girardo D, Govek EE, et al:: Role of Tet1/3 Genes and Chromatin Remodeling Genes in Cerebellar Circuit Formation. Neuron. 2016; 89(1): 100-12. PubMed Abstract | Publisher Full Text | Free Full Text | F1000 Recommendation

110. Ka M, Chopra DA, Dravid SM, et al.: Essential Roles for ARID1B in Dendritic Arborization and Spine Morphology of Developing Pyramidal Neurons. J Neurosci. 2016; 36(9): 2723-42. PubMed Abstract | Publisher Full Text | Free Full Text

111. Celen C, Chuang JC, Luo X, et al: Arid1b haploinsufficient mice reveal neuropsychiatric phenotypes and reversible causes of growth impairment. eLife. 2017; 6: pii: e25730. PubMed Abstract | Publisher Full Text | Free Full Text

112. Halgren $\mathrm{C}$, Kjaergaard S, Bak M, et al:: Corpus callosum abnormalities, intellectual disability, speech impairment, and autism in patients with haploinsufficiency of ARID1B. Clin Genet. 2012; 82(3): 248-55. PublMed Abstract | Publisher Full Text | Free Full Text

113. Hoyer J, Ekici AB, Endele S, et al:: Haploinsufficiency of ARID1B, a member of the SWI/SNF-a chromatin-remodeling complex, is a frequent cause of intellectual disability. Am J Hum Genet. 2012; 90(3): 565-72. PubMed Abstract | Publisher Full Text | Free Full Text

114. Santen GW, Aten E, Sun $Y$, et al:: Mutations in SWI/SNF chromatin remodeling complex gene ARID1B cause Coffin-Siris syndrome. Nat Genet. 2012; 44(4): 379-80.

PubMed Abstract | Publisher Full Text

115. Tsurusaki $\mathrm{Y}$, Okamoto $\mathrm{N}$, Ohashi $\mathrm{H}$, et al:: Coffin-Siris syndrome is a SWI/SNF complex disorder. Clin Genet. 2014; 85(6): 548-54. PubMed Abstract | Publisher Full Text

116. Shibutani M, Horii T, Shoji H, et al.: Arid1b Haploinsufficiency Causes Abnormal Brain Gene Expression and Autism-Related Behaviors in Mice. Int J Mol SCI. 2017; 18(9): pii: E1872. PubMed Abstract | Publisher Full Text | Free Full Text

117. F Ka M, Kim WY: ANKRD11 associated with intellectual disability and autism regulates dendrite differentiation via the BDNF/TrkB signaling pathway. Neurobiol Dis. 2018; 111: 138-52. PubMed Abstract | Publisher Full Text | Free Full Text | F1000 Recommendation

118. F Litke C, Bading H, Mauceri D: Histone deacetylase 4 shapes neuronal morphology via a mechanism involving regulation of expression of vascular endothelial growth factor D. J Biol Chem. 2018; 293(21): 8196-207. PubMed Abstract | Publisher Full Text | Free Full Text | F1000 Recommendation

119. Chiu $\mathrm{H}$, Alqadah $\mathrm{A}$, Chang $\mathrm{C}$ : The role of microRNAs in regulating neuronal connectivity. Front Cell Neurosci. 2014; 7: 283. PubMed Abstract | Publisher Full Text | Free Full Text

120. Loya CM, Van Vactor D, Fulga TA: Understanding neuronal connectivity through the post-transcriptional toolkit. Genes Dev. 2010; 24(7): 625-35. PubMed Abstract | Publisher Full Text | Free Full Text

121. F Burak K, Lamoureux L, Boese A, et al.: MicroRNA-16 targets mRNA involved in neurite extension and branching in hippocampal neurons during presymptomatic prion disease. Neurobiol Dis. 2018; 112: 1-13. PubMed Abstract | Publisher Full Text | F1000 Recommendation

122. Franzoni $\mathrm{E}$, Booker SA, Parthasarathy $\mathrm{S}$, et al.: miR-128 regulates neuronal migration, outgrowth and intrinsic excitability via the intellectual disability gene Phf6. eLife. 2015; 4: e04263. PubMed Abstract | Publisher Full Text | Free Full Text

123. Xue $Q, Y u C$, Wang $Y$, et al:: miR-9 and miR-124 synergistically affect regulation of dendritic branching via the AKT/GSK3 $\beta$ pathway by targeting Rap2a. Sci Rep. 2016; 6: 26781 PubMed Abstract | Publisher Full Text | Free Full Text

124. Xu Y, Quinn CC: Transition between synaptic branch formation and synaptogenesis is regulated by the lin-4 microRNA. Dev Boil. 2016; 420(1): $60-66$.

PubMed Abstract | Publisher Full Text | Free Full Text

125. Hamada $\mathrm{N}$, Ito $\mathrm{H}$, Iwamoto I, et al.: Role of the cytoplasmic isoform of RBFOX1/ A2BP1 in establishing the architecture of the developing cerebral cortex. $\mathrm{MO}$ Autism. 2015; 6: 56. PubMed Abstract | Publisher Full Text | Free Full Text

126. F Olesnicky EC, Bono JM, Bell L, et al:: The RNA-binding protein caper is 
required for sensory neuron development in Drosophila melanogaster. Dev Dyn. 2017; 246(8): 610-24.

PubMed Abstract | Publisher Full Text | Free Full Text | F1000 Recommendation

127. F Skariah G, Seimetz J, Norsworthy M, et al:: Mov10 suppresses retroelements and regulates neuronal development and function in the developing brain. BMC Biol. 2017; 15(1): 54.

PubMed Abstract | Publisher Full Text | Free Full Text | F1000 Recommendation

128. Goldberg JL: Intrinsic neuronal regulation of axon and dendrite growth. Curr Opin Neurobiol. 2004; 14(5): 551-7. PubMed Abstract | Publisher Full Text

129. F Haas MA, Ngo L, Li SS, et al.: De Novo Mutations in DENR Disrupt Neuronal Development and Link Congenital Neurological Disorders to Faulty mRNA Translation Re-initiation. Cell Rep. 2016; 15(10): 2251-65. PubMed Abstract | Publisher Full Text | Free Full Text | F1000 Recommendation

130. Brechbiel JL, Gavis ER: Spatial regulation of nanos is required for its function in dendrite morphogenesis. Curr Biol. 2008; 18(10): 745-50. PubMed Abstract | Publisher Full Text | Free Full Text

131. F Bhogal B, Plaza-Jennings A, Gavis ER: Nanos-mediated repression of hid protects larval sensory neurons after a global switch in sensitivity to apoptotic signals. Development. 2016; 143(12): 2147-59.

PubMed Abstract | Publisher Full Text | Free Full Text | F1000 Recommendation

132. Perycz M, Urbanska AS, Krawczyk PS, et al:: Zipcode binding protein 1 regulates the development of dendritic arbors in hippocampal neurons. J Neurosci. 2011; 31(14): 5271-85.

PubMed Abstract | Publisher Full Text

133. F Urbanska AS, Janusz-Kaminska A, Switon K, et al:: ZBP1 phosphorylation at serine 181 regulates its dendritic transport and the development of dendritic trees of hippocampal neurons. Sci Rep. 2017; 7(1): 1876. PubMed Abstract | Publisher Full Text | Free Full Text | F1000 Recommendation

134. F Misra M, Edmund H, Ennis D, et al:: A Genome-Wide Screen for Dendritically Localized RNAs Identifies Genes Required for Dendrite Morphogenesis. G3 (Bethesda). 2016; 6(8): 2397-405.

PubMed Abstract | Publisher Full Text | Free Full Text | F1000 Recommendation

135. F Wong HH, Lin JQ, Ströhl F, et al:: RNA Docking and Local Translation Regulate Site-Specific Axon Remodeling In Vivo. Neuron. 2017; 95(4): 852-868.e8. PubMed Abstract | Publisher Full Text | Free Full Text | F1000 Recommendation

136. Zhu W, Nelson CM: PI3K signaling in the regulation of branching morphogenesis. BioSystems. 2012; 109(3): 403-11. PubMed Abstract | Publisher Full Text

137. Hutchins BI, Li L: EphrinA and TrkB interact to promote axon branching J Neurosci. 2009; 29(14): 4329-31. PubMed Abstract | Publisher Full Text

138. Lee JR: Protein tyrosine phosphatase PTPRT as a regulator of synaptic formation and neuronal development. BMB Rep. 2015; 48(5): 249-55. PubMed Abstract | Publisher Full Text | Free Full Text

139. Spillane M, Gallo G: Involvement of Rho-family GTPases in axon branching. Small GTPases. 2014; 5(1): e27974.

PubMed Abstract | Publisher Full Text | Free Full Text

140. F Cosker KE, Segal RA: Neuronal signaling through endocytosis. Cold Spring Harb Perspect Biol. 2014; 6(2): pii: a020669.

PubMed Abstract | Publisher Full Text | Free Full Text | F1000 Recommendation

141. F Lim CS, Alkon DL: Inhibition of coactivator-associated arginine methyltransferase 1 modulates dendritic arborization and spine maturation of cultured hippocampal neurons. J Biol Chem. 2017; 292(15): 6402-13. PubMed Abstract | Publisher Full Text | Free Full Text | F1000 Recommendation

142. Lim CS, Alkon DL: Protein kinase $\mathbf{C}$ stimulates HuD-mediated mRNA stability and protein expression of neurotrophic factors and enhances dendritic maturation of hippocampal neurons in culture. Hippocampus. 2012; 22(12): 2303-19.

PubMed Abstract | Publisher Full Text

143. Kim JD, Park KE, Ishida J, et al.: PRMT8 as a phospholipase regulates Purkinje cell dendritic arborization and motor coordination. Sci Adv. 2015; 1(11): e1500615

PubMed Abstract | Publisher Full Text | Free Full Text

144. Plooster M, Menon S, Winkle CC, et al.: TRIM9-dependent ubiquitination of DCC constrains kinase signaling, exocytosis, and axon branching. Mol Biol Cell. 2017; 28(18): 2374-85.

PubMed Abstract | Publisher Full Text | Free Full Text

145. F Winkle CC, McClain LM, Valtschanoff JG, et al:: A novel Netrin-1-sensitive mechanism promotes local SNARE-mediated exocytosis during axon branching. J Cell Biol. 2014; 205(2): 217-32.

PubMed Abstract | Publisher Full Text | Free Full Text | F1000 Recommendation

146. Winkle CC, Olsen RH, Kim H, et al:: Trim 9 Deletion Alters the Morphogenesis of Developing and Adult-Born Hippocampal Neurons and Impairs Spatial Learning and Memory. J Neurosci. 2016; 36(18): 4940-58. PubMed Abstract | Publisher Full Text | Free Full Text

147. Garrett AM, Schreiner D, Lobas MA, et al:: $\gamma$-protocadherins control cortical dendrite arborization by regulating the activity of a FAK/PKC/MARCKS signaling pathway. Neuron. 2012; 74(2): 269-76. PubMed Abstract | Publisher Full Text | Free Full Text

148. Chen J, Lu Y, Meng S, et al:: alpha- and gamma-Protocadherins negatively regulate PYK2. J Biol Chem. 2009; 284(5): 2880-90. PubMed Abstract | Publisher Full Text | Free Full Text

149. Keeler AB, Schreiner D, Weiner JA: Protein Kinase C Phosphorylation of a $\gamma$ Protocadherin C-terminal Lipid Binding Domain Regulates Focal Adhesion Kinase Inhibition and Dendrite Arborization. J Biol Chem. 2015; 290(34): 20674-86. PubMed Abstract | Publisher Full Text | Free Full Text

150. Blizinsky KD, Diaz-Castro B, Forrest MP, et al:: Reversal of dendritic phenotypes in 16p11.2 microduplication mouse model neurons by pharmacological targeting of a network hub. Proc Natl Acad Sci U S A. 2016; 113(30): 8520-5. PubMed Abstract | Publisher Full Text | Free Full Text

151. Xing L, Larsen RS, Bjorklund GR, et al:: Layer specific and general requirements for ERK/MAPK signaling in the developing neocortex. eLife. 2016; 5 : pii: e11123.

PubMed Abstract | Publisher Full Text | Free Full Text

152. F Li D, Musante V, Zhou W, et al.: Striatin-1 is a B subunit of protein phosphatase PP2A that regulates dendritic arborization and spine development in striatal neurons. J Biol Chem. 2018; 293(28): 11179-94. PubMed Abstract | Publisher Full Text | Free Full Text | F1000 Recommendation

153. F Nakamura F, Okada T, Shishikura M, et al:: Protein Tyrosine Phosphatase $\delta$ Mediates the Sema3A-Induced Cortical Basal Dendritic Arborization through the Activation of Fyn Tyrosine Kinase. J Neurosci. 2017; 37(30): 7125-39. PubMed Abstract | Publisher Full Text | F1000 Recommendation

154. Dascenco D, Erfurth ML, Izadifar A, et al:: Slit and Receptor Tyrosine Phosphatase 69D Confer Spatial Specificity to Axon Branching via Dscam1. Cell. 2015; 162(5): 1140-54

PubMed Abstract | Publisher Full Text | Free Full Text

155. Yamamoto N, López-Bendito G: Shaping brain connections through spontaneous neural activity. Eur J Neurosci. 2012; 35(10): 1595-604. PubMed Abstract | Publisher Full Text

156. Matsumoto N, Hoshiko M, Sugo N, et al.: Synapse-dependent and independent mechanisms of thalamocortical axon branching are regulated by neuronal activity. Dev Neurobiol. 2016; 76(3): 323-36. PubMed Abstract | Publisher Full Text

157. Almeida OP, Schwab SG, Lautenschlager NT, et al:: KIBRA genetic polymorphism influences episodic memory in later life, but does not increase the risk of mild cognitive impairment. J Cell Mol Med. 2008; 12(5A): 1672-6. PubMed Abstract | Publisher Full Text | Free Full Text

158. Bates TC, Price JF, Harris SE, et al.: Association of KIBRA and memory. NeurosC Lett. 2009; 458(3): 140-3. PubMed Abstract | Publisher Full Text

159. Johannsen $\mathrm{S}$, Duning $\mathrm{K}$, Pavenstädt $\mathrm{H}$, et al: Temporal-spatial expression and novel biochemical properties of the memory-related protein KIBRA. Neuroscience. 2008; 155(4): 1165-73. PubMed Abstract | Publisher Full Tex

160. F Papassotiropoulos A, Stephan DA, Huentelman MJ, et al.: Common Kibra alleles are associated with human memory performance. Science. 2006; 314(5798): 475-8.

PubMed Abstract | Publisher Full Text | F1000 Recommendation

161. F Heitz FD, Farinelli M, Mohanna S, et al.: The memory gene KIBRA is a bidirectional regulator of synaptic and structural plasticity in the adult brain. Neurobiol Learn Mem. 2016; 135: 100-14. PubMed Abstract | Publisher Full Text | F1000 Recommendation

162. Haas K, Li J, Cline HT: AMPA receptors regulate experience-dependent dendritic arbor growth in vivo. Proc Natl Acad Sci U S A. 2006; 103(32): 12127-31. PubMed Abstract | Publisher Full Text | Free Full Text

163. F Shimada T, Yoshida T, Yamagata K: Neuritin Mediates Activity-Dependent Axonal Branch Formation in Part via FGF Signaling. J Neurosci. 2016; 36(16): 4534-48

PubMed Abstract | Publisher Full Text | F1000 Recommendation 


\section{Open Peer Review}

\section{Current Peer Review Status:}

\section{Editorial Note on the Review Process}

Faculty Reviews are review articles written by the prestigious Members of Faculty Opinions. The articles are commissioned and peer reviewed before publication to ensure that the final, published version is comprehensive and accessible. The reviewers who approved the final version are listed with their names and affiliations.

\section{The reviewers who approved this article are:}

\section{Version 1}

\section{Elizabeth R. Gavis}

Department of Molecular Biology, Princeton University, Princeton, NJ, USA

Competing Interests: No competing interests were disclosed.

\section{Woo-Yang Kim}

Department of Biological Sciences, Kent State University, Kent, OH, USA

Competing Interests: No competing interests were disclosed.

The benefits of publishing with F1000Research:

- Your article is published within days, with no editorial bias

- You can publish traditional articles, null/negative results, case reports, data notes and more

- The peer review process is transparent and collaborative

- Your article is indexed in PubMed after passing peer review

- Dedicated customer support at every stage

For pre-submission enquiries, contact research@f1000.com 